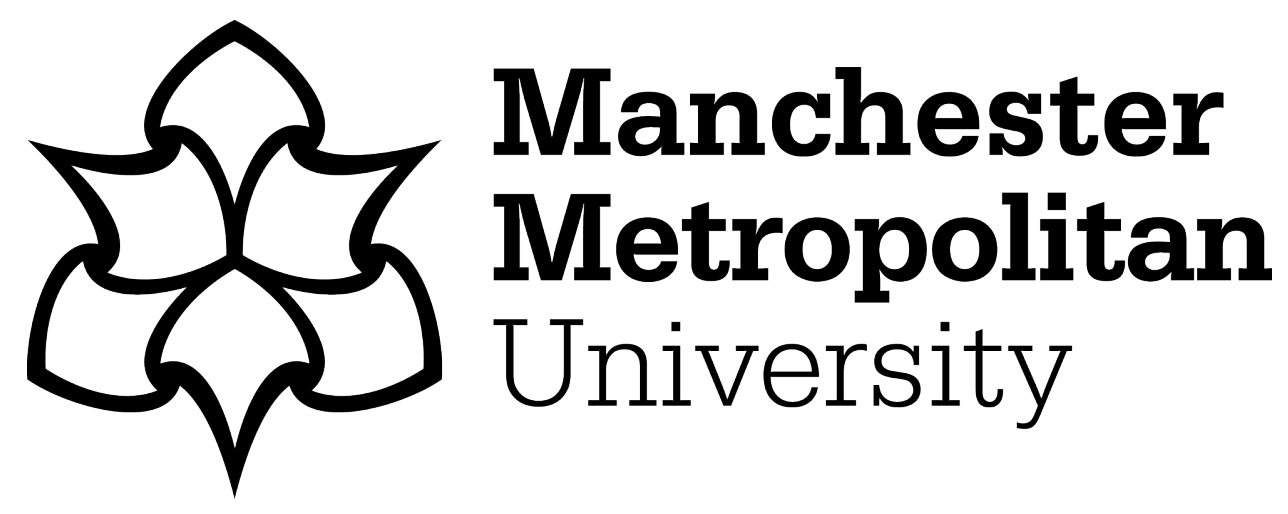

Day, David (2018) Swimming Natationists, Mistresses, and Matrons: Familial Influences on Female Careers in Victorian Britain. International Journal of the History of Sport, 35 (6). pp. 494-510. ISSN 0952-3367

Downloaded from: https://e-space.mmu.ac.uk/622409/

Version: Accepted Version

Publisher: Taylor \& Francis (Routledge)

DOI: https://doi.org/10.1080/09523367.2018.1543271

Please cite the published version 


\title{
Swimming Natationists, Mistresses and Matrons: Familial Influences on Female Careers in Victorian Britain
}

\begin{abstract}
:
The long Victorian period has often been interpreted through the lens of 'separate spheres', a notion that suggests a compartmentalization of markers like gender and class into discrete areas. However, the margins surrounding class and gender were full of fissures and scholars have argued for more nuanced research involving specific case studies at a micro level to uncover the breadth and boundaries of female experience. Adopting this micro approach by using archives and biographical methods to investigate the communities of women involved in swimming-related careers during the nineteenth and early twentieth centuries yields new insights into the complexities of 'separate spheres' ideologies. Serious swimming became acceptable for women of all social classes after facilities expanded following the Baths and Washhouses Acts of 1846 and 1878, and a moral imperative, which required women to be attended to only by women, meant that gender-specific career routes gradually emerged. The class origins and familial connections of female natationists, swimming teachers and baths employees are explored, to place them within the contemporary social context and to draw some tentative conclusions about sport, 'separate spheres' and the ongoing influence of patriarchy on female occupational choices. Reflections on the potential for combining different biographical methods to produce a 'blended approach' are then offered.
\end{abstract}

\section{Keywords}

Biography, Swimming, Separate spheres, Patriarchy, Gender 
By the mid-nineteenth century the role of women in the workplace had been firmly established and when the English Woman's Journal analysed the 1851 census returns it estimated that $3,107,791$ females over fifteen were being employed out of a population of $7,043,701 .{ }^{1}$ While most of these women came from the working class, class being assessed here with reference to occupational status of husbands and fathers, ${ }^{2}$ thousands of middle-class women were also engaged in a range of occupations, although reformers were beginning to place a different emphasis on the social value and place of women. Ideas of 'refinement' increasingly prescribed a life of idleness for middle-class women, unless absolute necessity ruled otherwise, and, even then, they were limited to genteel trades like dressmaking or to what Charlotte Bronte described as 'governessing slavery'. ${ }^{3}$ Gradually, the middle-class family assumed a different form, as Victorian culture sentimentalized women's family lives. In Sesame and Lilies, John Ruskin articulated the philosophy of 'separate spheres', and claimed that women were best equipped for the private or domestic realm, while men were naturally suited to the active, aggressive, and intellectual domains of public life. ${ }^{4}$ Leonore Davidoff and Catherine Hall argued that this ideology emerged as an integral part of the process of middle-class formation and that middleclass women subsequently withdrew from public life to concentrate on their domesticity, ${ }^{5} \mathrm{a}$ perspective that remains influential among scholars who believe that this period witnessed the demarcation of family life as private, sentimental, and feminine in opposition to the masculine world of public affairs. ${ }^{6}$

There have been subtle and challenging analyses of this public/private dichotomy and the concept of 'separate spheres' has been critiqued by historians who have highlighted longterm continuities in the basic structure of women's work, thereby contradicting the argument that women's employment was constricted by capitalism and industrialization. ${ }^{7}$ Amanda Vickery argued that a basic separation of spheres could be applied to any culture and/or time period while Robert Shoemaker suggests that the limited impact of ideological prescriptions on day-to-day practice meant that the spheres were never truly separate, especially further down the social scale. ${ }^{8}$ While Theodore Koditschek believes that a form of separate spheres domesticity gradually became a reality for most working people, ${ }^{9}$ Geoffrey Best points out that the 'sentimental writers who enthused about The Home and about woman's place within it' were never describing a normal domestic situation for most of the working classes. ${ }^{10}$ As Gerry Holloway contends, in contrast to their middle-class counterparts, who were often salaried and in supervisory positions, working-class women engaged in waged manual work and they were ghettoized into unskilled, insecure, low-paid occupations. ${ }^{11}$

Irrespective of issues of class, Mary Poovey argued that the negotiation of sphere boundaries was full of fissures. ${ }^{12}$ Consequently, the socially defined margins established for appropriate class and gender behaviour were always permeable and it cannot be assumed that women of any class or marital status were necessarily restricted to the home. Those women whose occupations transcended notional class boundaries deserve especial consideration since not all social classes have been treated equally by historians. Studies of gender amongst the nineteenth-century lower-middle classes remain scarce, ${ }^{13}$ while Richard Holt's observation in 1996 that the lower middle class seemed especially obscure in leisure histories still resonates. ${ }^{14}$ There is no obvious reason why this should be the case since new technology has enabled a reassessment of sources and access to archives, and researchers now utilize a range of qualitative and quantitative methods. ${ }^{15}$ For those interested in biographies, quantitative 
methods such as prosopography - whereby details of a group of historical actors are collated to identify and analyse trends in the data - can help contextualize historical processes and explain ideological or cultural change, especially within previously hidden strata of society, as well as the influence of family on life courses. Wray Vamplew, for example, identified that the number of golf professionals grew from 679 in 1907 to 941 in 1913 and that $64.7 \%$ of professionals shared their surname with at least one other professional, thereby uncovering the importance of kinship to this group. ${ }^{16}$ Samantha-Jayne Oldfield has observed that the changing nature of historical thinking has stimulated the emergence of a 'new' prosopography, which still discusses persons according to name and highlights the social context of groups, but is also concerned with the networks they created. ${ }^{17}$

On the downside, a large-scale quantifiable approach can marginalize individual lives, depriving historical narrative of its richness, and more detailed individual biographies can often better illuminate previously hidden lives and individual experiences. As Philip Abrams argued, 'history' happens at the micro-social level of individuals, so historians should strive to capture what was important to the people who lived their lives, irrespective of their social status. ${ }^{18}$ For Beverly Lemire, the 'humble, ubiquitous practices that characterized plebeian lives are fertile ground for historical enquiry, mirroring in their collective daily acts the evolving expectations and aspirations of each generation'. ${ }^{19}$ However, learning about the mundane is more difficult than investigating the extraordinary and exposing these lives is not an easy undertaking. Joyce Kay pointed out that the lives of many ordinary suffrage activists and sportswomen went unrecorded and Jeffrey Hill suggested that reconstructing the experiences of ordinary people requires the interrogation of new kinds of sources, as well as an imaginative use of methods. ${ }^{20}$ Since the individual life course cannot, on its own, lead to any definitive conclusions about wider experiences of class and gender, it pays historians to consider combining different biographical approaches, not only to uncover previously hidden lives, connections and networks but also to add significantly to wider historical debates, such as those surrounding gender and women's engagement in sport.

Contemporary scholars have argued for a more nuanced approach to studying the diversity of female experiences involving specific case studies that explore economic roles, social lives, institutional opportunities and personal preoccupations, to illustrate how gender and class intersected at a micro level. ${ }^{21}$ In addition, while prosopography is beginning to be used to interrogate nineteenth and twentieth century populations, often on quite a small scale, this approach is in its early stages and there is a need for further prosopographical studies in subject specific areas, such as sport. ${ }^{22}$ These issues are addressed in this paper, through an investigation of the social impact of an increase in Victorian public baths and washhouses, which provided a working environment for both single and married women. This is part of an ongoing project that will eventually involve engaging with all biographical methods but has started by creating a still-evolving prosopographical database of women with swimming connections compiled from census data collected in England and Wales between 1841 and $1911,{ }^{23}$ to explore class origins and to trace career trajectories. One focus is on the influence of male family connections and the implications this has for assessing the impact of patriarchy, a system in which men have all or most of the power and importance in a society or group, on female life courses and their swimming-related careers. 


\section{Women in Sport}

Nineteenth-century women may have adopted many roles in society, but they did not enjoy infinite possibilities, ${ }^{24}$ especially in activities such as sport. Because individuals operate within the constraints of their social world, inequalities such as those related to social status and gender are always reflected within the sporting landscape, ${ }^{25}$ so the separate spheres argument, providing it is valid, supposedly shaped concepts of what were suitable physical activities for women and established limited behavioural and spatial boundaries, ${ }^{26}$ based on both class and gender. ${ }^{27}$ In her role as sportswoman, as in her role as wife and mother, a woman was expected to behave in an exemplary fashion and to display feminine traits, ${ }^{28}$ while remaining subservient to the male in all respects. Kathleen McCrone notes that team sports were believed to develop character traits normally reserved for men and that if women played them without restriction, the sports would be feminized, and women masculinized. Women found acceptance more easily in individual sports such as archery, lawn tennis and golf, which required membership in socially exclusive, often mixed, clubs, and involved the production of aesthetically pleasing images, thus according much more with social and cultural images of genteel womanliness. ${ }^{29}$ It needs to be recognized though that distinctive class differences always existed within this gender context and McCrone highlights the dangers of adopting 'illusions of sisterly solidarity' since women had no desire to associate on the playing field with people they would never have entertained in their drawing rooms. ${ }^{30}$ Furthermore, Catriona Parratt has criticized the explanatory models, theories, and perspectives on class used by many historians of women's sport, because of their concentration on the experiences of educated, bourgeois females to the exclusion of working-class women. ${ }^{31}$ For example, the femininity question which hindered the development of middle-class games players was less of a problem for lower order women who were normally excluded from society's definition of 'feminine,' and thus concerns about the effects on 'ladies' of physical overstrain. ${ }^{32}$

\section{Swimming}

Although both sexes in Britain engaged in sea bathing at the beginning of the nineteenth century, often under the supervision of local 'bathers', swimming for exercise remained a primarily male activity. As the century progressed, swimming became socially acceptable for women because it had value as a lifesaving activity, it took place in an environment that masked physical effort, and it provided beneficial exercise in segregated surroundings. ${ }^{33}$ Female doctors were among its leading advocates on the basis that it was good for the lungs and allowed women to use their muscles in a natural and healthy manner, while also helping them to bear healthy children. ${ }^{34}$ Widening female participation was facilitated by an increase in provision following the 1846 Baths and Washhouses Act and the subsequent Public Baths and Washhouses Act of $1878,{ }^{35}$ which stimulated the building of baths for personal hygiene or swimming and washhouses for laundry. By 1915, there were 343 public baths and 69 washhouses in Britain, maintained by public authorities who encouraged schools' swimming, charged low prices, thus enabling working-class access, ${ }^{36}$ employed swimming teachers, and made at least some provision for women swimmers, many of whom were taking the activity seriously. Aquatic enthusiasts could be found in all levels of the social hierarchy and in all parts 
of the country. The clientele of the Brighton Baths included many aristocratic women, as did the Bath Club in London, while middle-class women enjoyed swimming in other London clubs such as the Ladies (Amateur) Cadogan Swimming Club and the Ladies' Tadpole Swimming Club. Swimming was increasingly encouraged among schoolgirls, ${ }^{37}$ and by 1898 there were many 'working women's clubs', ${ }^{38}$ although the physical realities of childbearing and child-care left most working-class women with little time for leisure. ${ }^{39}$

Despite its popularity, patriarchal baths' committees initially only set aside one or two days per week for women, perhaps just for a few hours at a time and generally at the least popular opening times. The Dulwich Baths for example, consisted of two baths but ladies' day was scheduled only for Wednesdays, $10 \mathrm{am}$ to $5.30 \mathrm{pm} .{ }^{40}$ Even when dedicated facilities were provided, female swimmers found their swimming spaces restricted. At the Lambeth Baths, opened in 1897, the first-class men's pool was 132 feet by 40 feet while the women's pool was 56 feet by 25 feet. In the winter season, only the women's pool was opened and used as a firstand second-class men's pool and a women's pool, in rotation. This practice had repercussions for the professional swimmers who used these facilities and for the increasing number of women employed in various categories at the baths, from swimming teachers, cashiers and matrons to bath attendants. ${ }^{41}$ Many of these roles had emerged following the 1846 and 1878 Acts, which had increased facilities and stimulated a limited degree of gender equality in the work-place as more women participated in segregated spaces.

\section{Professional Swimmers}

An emerging sport and leisure culture in the Victorian period provided opportunities for several working-class female professional swimmers ('natationists'), who were influential in generating an interest in swimming among women of all classes, not least through their aquatic demonstrations and teaching of skills in the public baths. Natationists displayed diving skills, held their breath underwater, swam in endurance events, raced for money, produced and performed in aquatic entertainments, and taught swimming and lifesaving. A popular feature of their performances was ornamental or scientific swimming, which displayed a range of aquatic skills in an artistic manner much like modern-day synchronized swimming. In terms of remuneration, Violet Mitchell was paid $£ 2$ per week in 1893, and four years later, swimmers at the Westminster Aquarium were being paid between $£ 1$ and $£ 2$ per week, although high divers like Annie Luker were paid substantially more. These women generally received much more public approval than other professional sportswomen, partly because of their age, marital status and bodily appearance, and partly because swimming had become an acceptable female activity. While their physical appearance had much to do with their appeal to many male admirers, their skill was widely appreciated, primarily because female spectators would become accustomed to seeing females swimming easily and would want to 'acquire the knowledge and skill which would enable them to do the same'. The contribution that their public exhibitions made to the development of female swimming was significant and, thanks partly to their example, swimming became a popular means of providing women with a 'counterpoise to their more sedentary employments and physically less active life'. ${ }^{42}$

The research conducted to this point suggests that this was a viable means of earning a living for several women in this period and the evidence provided by the occupation of their 
fathers and spouses confirms that they generally emerged from the margins between the working and middle class. Olivette Flower, who appeared regularly with swimming troupes around the country, had a father who was a railway guard, Maud Elmore's father was a joiner, Alice Wood's father was an assurance agent, and Mary Cochrane's father was an accountant. Other occupations ranged from master cabinet maker to gas fitter and mercantile clerk. Many of these women had family connections to the activity and it is here that the patriarchal influence on career choices becomes obvious. Alice Beaumont's husband was a professional swimmer and hotel keeper, Florence Tilton's father was a baths superintendent, Edna Wilson's father was a swimming teacher, as was Mary Phillips' father, while Alice Randall's brother was also a professional swimmer. The development of swimming throughout the century relied heavily on the activities of these swimming families, who included summer seasons at seaside resorts as well as appearances in variety theatres and music halls.

Female family members proved particularly popular and families like the Wards and the Finneys relied heavily on their contributions to attract spectators to their shows. Alfred Ward was an 'agent, teacher of swimming and dancing' living in Hampstead in 1881, along with ten-year-old Minnie, and in 1883, Ward, then engaged as swimming master at Hammersmith Baths, gave an exhibition in Ramsgate with his 'naiad' of a daughter, 'whose grace and dexterity in the water are well worth witnessing'. By 1891, Ward was living in Kensington with Alfred (eighteen), 'professional swimmer and stationary assistant', Florence (seventeen), 'professional swimmer and upholsters helper', Ernest (fifteen), 'professional swimmer and bookbinder's assistant', and Maud (thirteen) 'professional swimmer'. ${ }^{43}$ James Finney, one of the few aquatic entertainers who managed to sustain his career into the twentieth century, was only eighteen in 1881 but already a 'teacher of swimming' in Oldham. He was a regular competitor during the 1880s and well known in the music halls, and his attempt on the underwater record at the Canterbury Music Hall in Lambeth in April 1886 attracted a large audience. He often performed alongside his sister Marie (Mary), who was presented with a gold medal in 1889 in recognition of her 'clever and plucky dive' from London Bridge. Following the example set, among others, by the Beckwith family in the 1880s, Finney appeared in America with Marie in 1894 and he was back in America with daughter Elsie several times between 1906 and 1910. He also spent much of 1911 in America performing with Elsie, as did his other daughters Maud Evelyn and Ethel Gladys, both professional swimmers. ${ }^{44}$ A similar scenario is played out wherever aquatic families appear in the records and it is reasonable to surmise that these female professionals, while transcending traditional notions of feminine behaviour and stretching the credibility of the 'separate spheres' argument, might not have been entirely self-selecting in terms of their career choice. As in similar activities such as the circus, their personal desires were likely to be superseded by the needs of the family and the wishes of the patriarch. In this respect, they were not alone since a similar trend can be identified in other swimming-related working communities such as teachers.

\section{Swimming Teachers}

The art of swimming required instruction, and the opportunity for a female to earn a living as a professional swimming teacher was a direct result of the increasing popularity of the activity among women, an expansion in indoor facilities and ongoing concerns about maintaining the 
segregation of the sexes. The socially preferred practice of swimming teachers teaching their own sex became entrenched during the nineteenth century with one author observing that it was not possible for a girl's father or brothers to teach her swimming since the English had not yet adopted the French approach, which was much more relaxed about males teaching females, and 'it is to be hoped we never shall'. In 1859, the Leeds Times appealed for female swimmers to pass on their expertise to the next generation and suggested that swimming mistresses could be brought over from France, ${ }^{45}$ while another writer suggested that if a swimming mistress was attached to each bath, females might 'readily learn an art which would assist in prolonging and saving many a life'. ${ }^{46}$ Gradually, as swimming teaching became more widely accepted as an appropriate way for a woman to earn a livelihood, the supply of female professional teachers increased to the point where Bell's Life was bemoaning in 1879 the general apathy about female swimming given that there was no lack of female teachers. ${ }^{47}$ In 1889, the Excelsoir Ladies Swimming Club, which met once a week at the Battersea Baths and had many school mistresses among its members, engaged a swimming mistress for instruction during the summer. ${ }^{48}$ Outside London, the ladies swimming club in Rochester, Kent, reported in 1884 that one of the club's employees taught any members who needed assistance with improved swimming techniques. ${ }^{49}$ When the Portsmouth Club advertised that same year for a female attendant who was able to swim and instruct, they were offering fifteen shillings a week for 10am to $4 \mathrm{pm}$ each day, $2 \mathrm{pm}$ on Saturdays with Sundays free. ${ }^{50}$ In 1885, the club employed Helga Lassen of Copenhagen to act as its 'lady instructress' and she gave displays of ornamental swimming at the club's gala. ${ }^{51}$

In one or two exceptional cases, swimming teachers were able to consolidate their newly acquired social position and it is here that individual biographies can be more revealing than quantitative studies. Fanny (Nellie) Easton, for example, worked as a swimming mistress at the Hornsey Road Baths between 1881 and 1911, as well as organizing and appearing in swimming entertainments, and her life course hints at the possibilities for social mobility that the swimming mistress role may have provided for some women. She was born in Middlesex in 1854 to cordwainer Charles Dear and wife Emma, and married to James Allford in 1873. ${ }^{52}$ A year later she was in the divorce courts accused of co-habiting with costermonger Levi Jackson, committing adultery with an unknown man in Hyde Park, and leading the life of a common prostitute. The judge found for the husband and the divorce was made absolute in 1875. ${ }^{53}$ Two years later, Fanny, described as a spinster and machinist, married David Easton, a shorthand clerk, ${ }^{54}$ whose brother, T.C. Easton, later became Honorary Secretary of the Professional Swimming Association. ${ }^{55}$ Despite her chequered early life, Nellie subsequently established herself as a highly respected teacher and aquatic entertainer. By the 1881 census, she was describing herself as a swimming mistress and over the next thirty years, she appeared regularly inside and outside of London, with and without her pupils. ${ }^{56}$ By 1888, she was swimming mistress at nine Metropolitan Baths and her aquatic exhibitions were proving extremely popular. ${ }^{57}$ At Bath in 1888, Nellie was introduced as the most accomplished lady swimmer in England and someone who had taught more women to swim than any other female teacher in Britain. During her exhibition, she went through several different styles of swimming, including revolving in the water. ${ }^{58}$ Described as a charming and beautifully proportioned woman, her promotions emphasized that she never wore corsets in the water and the public were invited to inspect her clothing to double check. ${ }^{59}$ 
Nellie was extremely active during the 1890s. In Bristol in September 1890, Nellie and her pupil Ada Clare went through a programme of eighteen items of ornamental swimming and floating, ${ }^{60}$ and when the Islington baths in Hornsey Road were opened in July 1892, Nellie, the swimming instructress, gave an exhibition. ${ }^{61}$ In August 1891, 'three clever lady swimmers', Nellie, Belle White and Rose Gamble, appeared at Ilfracombe Hotel Baths, ${ }^{62}$ and Belle White was with Nellie again in Bristol in September, giving an exhibition of ornamental swimming and floating that was loudly applauded. ${ }^{63}$ At the opening of the Dulwich Baths in 1892, Nellie and her pupils gave an aquatic display of ornamental swimming, ${ }^{64}$ and she was at Ilfracombe again in August with Belle White, Connie Stevenson and Rose Potter. ${ }^{65}$ When the Camberwell Public Baths and Wash houses opened in October 1892, Nellie and her pupils gave an exhibition of swimming and floating. ${ }^{66}$ She acted as starter at the annual swimming competitions of the Girls' Division of the London Pupil Teachers' Association at the Hornsey Road Baths in 1893, ${ }^{67}$ and gave swimming entertainments at the Baths in September 1894, assisted by many of her lady pupils, ranging from babies upwards, who made a 'grand show, none having the slightest fear of the water, plunging and swimming about like so many ducks'. Nellie, 'besides being a perfect swimmer herself, certainly has the power to impart her skill to that of her pupils' ${ }^{68}$ As well as being an excellent performer and teacher, it seems that Nellie was also able to manage her own self-employed career. In the 1901 census Nellie was describing herself as a 'swimming mistress (Own account)' and ten years later she was a 'swimming instructress', again working on her 'Own account', at the County Council Public Baths. ${ }^{69}$ Remarkably, especially in the light of the financial difficulties experienced by many of those working in swimming, when she died on 19 June 1919, she left effects worth $£ 2,723$ 10s. 9d (just over $£ 280,000$ in today's money). ${ }^{70}$

Throughout the long Victorian period opportunities expanded for those with expertise like Nellie, and the census data shows an increasing number of females giving swimming teaching as their occupation. Nine swimming mistresses were recorded in 1871, increasing to 110 by 1911 . In recording this data, only individuals who used the term swimming 'mistress', 'teacher' or 'instructor' were considered and those who taught swimming but preferred to call themselves something else, such as aquatic entertainer, bath attendant or professional swimmer, have been excluded. In all, 162 swimming teachers who met this criteria were positively identified, and the evidence suggests that the class of women involved was consistent with that of the natationists. Where fathers' and/or husbands' occupations have been identified these highlight a certain stratum of Victorian and Edwardian society with these men working as foremen, coachbuilders, plumbers, joiners, shoemakers, engineers, plasterers and so on. In all, $62 \%$ of father and husbands followed occupations that involved crafts, clerk or office work or running a small business. This similarity in class origins, which places most of these women on the boundary between skilled working class and the lower middle class, is not surprising since there was considerable crossover between these swimming constituencies with teachers performing entertainments and natationists running teaching classes.

There are also similarities between the groups in terms of patriarchal influence. In sports like swimming, where finesse and skill were paramount, family involvement tended to be sustained over generations and in several instances, women were apparently introduced into the occupation by male relatives with $33 \%$ of fathers or husbands having an occupation related to swimming. William Tuohy was giving swimming exhibitions in 1851 and fifty years later 
his whole family was involved in swimming. Tuohy was a 'swimming instructor' and Sarah, his wife, was a 'swimming instructress', as were daughters Sarah and Mary, both of whom later taught swimming in Nottingham. ${ }^{71}$ Fathers like William were especially important facilitators of female teaching careers. In 1879, Miss Whyte, swimming mistress at the Chelsea and South Kensington Baths, was afforded a financially successful benefit at which she went through some 'clever feats of natation'. ${ }^{72}$ Her father, Charles Whyte, was variously the swimming master and instructor at Harrow School, and the 'professor in residence' at the King Street Baths, Camden Town. He sat on the first committee of the Professional Swimming Association in 1881, and as swimming master at Paddington Public Baths he organized annual swimming entertainments. Having married and become Mrs Crocker, she was still the swimming teacher at the Kensington baths in 1893 where her 'able system of training' had turned many novices into accomplished swimmers. She was a 'clever and painstaking teacher and very popular in the club' and five of her pupils passed the Life Saving Society examination in $1895 .{ }^{73}$ Other prominent practitioners included the Humphrey sisters, Charlotte and Jane, whose father had been a leading swimming teacher and organizer, as well as working as a shoemaker and boat builder, and several similar examples of patriarchal influence can be observed in much of the current data. Swimming teachers such as Kate and Lizzie Boon were the daughters of a swimming instructor, as were Honora and Amy Leahy, while others, such as Annie McGarrick, Gertrude Hall, and sisters Margaret, Edna and Elsie Leadbetter, were the daughters of baths superintendents.

\section{Baths Employees}

The new baths facilities required staffing, ranging from the matrons who adopted managerial roles to the laundresses and washerwomen at the other end of the social scale. Reflecting their status with baths committees and customers, the 'servants' listed at the Hastings baths in 1873 included a ticket clerk, a carpenter, an engineer, a laundress and male and female bath attendants who were paid 10 shillings a week. ${ }^{74}$

It should be noted at this point that there are significant difficulties in identifying those attendants specifically employed at public baths and washhouses rather than in other facilities such as Turkish baths or medical establishments. Census records rarely enable the researcher to distinguish between these positions and, even within the public baths, the term 'bath attendant' encompassed many different roles, including cleaning, attending to people in the individual baths, lifesaving, and working in the ticket office. The emerging data is, therefore, being subjected to as much scrutiny as is possible through triangulation with other sources, although the further one goes down the social scale the more problematic this becomes since the study of previously hidden individuals is the study of those who rarely appear in the records. Newspaper reports, for example, generally ignored the lowly bath attendant although they can provide supporting evidence for those in the more respected supervisory positions such as matrons. 


\section{Attendants}

Bath attendants played an essential part in the running of the baths, although their role, which often included teaching swimming, was always fluid with individuals working around the facility according to demand. In 1887, John Butters observed there were a number of competent teachers on the staff at the Edinburgh Baths but from 'excess of work' they were unable to devote any attention to teaching, their time being devoted to the safety of swimmers, cleaning, and attending to customers requiring hot baths. ${ }^{75}$ Some of these duties might take them into the front office, and adverts from Leeds in 1895 and Liverpool in 1899 also specified that applicants for the role of 'female attendant and clerk' at the public baths had to be able to swim. ${ }^{76}$ As with swimming teachers, attendants normally looked after bathers of their own sex, although women were paid less than men. The weekly wage of a male bath attendant in Liverpool in 1856 was 24 shillings, not much better than the average manual wage of the period, ${ }^{77}$ but when the Portsmouth Club advertised in 1884 for a female attendant who was also able to teach they only offered fifteen shillings a week for up to six hours a day with Sundays free. ${ }^{78}$ At Dulwich Baths in 1892, Mrs Mary Anderson was hired for twenty shillings a week, while William Sanderson received twenty-five shillings. ${ }^{79}$

In all, 1,242 female bathing attendants have been identified so far and the census data indicates an increasing number of females giving 'bath attendant' as their occupation, especially after the 1878 Act, with the 75 bath attendants recorded in 1871 rising to 455 by 1911 . Both married and single women were involved, although the 'single' category needs further investigation since there may be some important conclusions to be drawn here about the category of 'widows', many of whom would have become single again in their fifties. ${ }^{80}$ It has been possible so far to categorically identify the occupations of fathers and husbands of 464 women engaged as bath attendants between 1851 and 1911 and the data shows that 37 out of $223(17 \%)$ fathers had baths connections and that 106 of the 241 (44\%) husbands were similarly engaged. The proportion of those with family connections appears to reduce steadily throughout this period suggesting that the occupational area was becoming more widely available. Unlike the natationists and teachers, it seems that a family background in the activity was not always a significant factor and this probably relates to the more menial and less specialized role that the bath attendant played, in which high levels of transferable knowledge were not required. In addition, the class of women involved was essentially similar across censuses with significant numbers emerging from the skilled working classes and lower middle-class. Despite the lower status afforded to this position in the baths, fathers' or husbands' occupations included mechanical engineer, carpenter and railway engine driver, although there are some signs of lower status occupational backgrounds, such as firewood cutter and restaurant waiter.

\section{Matrons}

A married couple were often employed as baths' superintendent and matron and lived above the baths. Richard Whitehead and his wife, Anne, were appointed to Blackfriars-street Public Baths, Salford, in 1880, when Richard received $£ 91$ per annum and Anne $£ 26$ per annum, plus accommodation on-site in the purpose-built staff apartment, with free coal, gas, and water. ${ }^{81}$ 
When the Cardiff Corporation advertised for a general manager and wife, to attend the ladies' baths, they offered a joint salary of $£ 70$ per annum with accommodation, coal and gas provided free of charge. ${ }^{82}$ Typically the husband would hire the staff and run the baths while his wife acted as money-taker, ${ }^{83}$ as well as providing a public face for the couple. Visitors to the Ladies' Tadpole Swimming Club races in September 1893 were entertained to tea by Mrs Middleweek, the matron, who was 'courtesy itself'. ${ }^{84}$ Reflecting the ongoing influence of patriarchy with respect to swimming-related careers, part of the attraction of the post of superintendent and matron was that other family members could be employed. John Howarth was bath superintendent at Victoria Baths in Ormskirk in 1871 and he was still the baths manager in 1881 when wife Agnes was the matron and daughter Frances was a swimming teacher. The 1891 census lists John as the baths manager, Agnes as superintendent and both Frances, now aged twenty-six, and nineteen-year-old Edith as teachers of swimming. ${ }^{85}$ The evidence highlights this family influence in determining women's engagement at supervisory level within the baths. Of 241 matrons, 219 had familial connections to the baths (91\%) with 206 of these $(94 \%)$ being married to the baths manager/superintendent. The data also suggests that there was a degree of longevity in these positions with many women remaining in these roles for up to three censuses.

\section{Conclusion Reflecting on patriarchy and prosopography}

This paper represents a commentary on, and interpretation of, the early findings of a long-term research project designed to understand female swimming careers and to place them in their social context. The overall picture given by the data collected to this point indicates that an increasing number of Victorian and Edwardian working-class women, both married and single, were being employed within the new public baths, often because of family influence, although this depended on the level at which they were engaged. The different career routes discussed here reflected a status hierarchy within the female swimming community with older, married matrons overseeing the working lives of less respectable colleagues such as baths attendants and laundry women, while natationists and swimming teachers occupied a societal position that seems to resonate with that of their origins within the skilled artisan class. These differences could be hypothesized by relating the findings on social class to contemporary notions of social status (see Table 1).

Table 1. Nineteenth-Century Females Roles at the Baths: Approximate Class and Status Hierarchy Sources: National Readership Survey; National Statistics Socio-economic Classification

\begin{tabular}{|l|l|l|l|}
\hline Role & NRS & NS-SEC & Social Capital \\
\hline Matron & C1 Supervisory & 3 Intermediate Occupation & High - respectable \\
\hline Natationists & C2 Skilled Manual & 4 Self-employed & High - but less respectable \\
\hline Swimming Teacher & C2 Skilled Manual & 4 Self-employed & Medium - higher over time \\
\hline Ticket Clerk/Cashier & D Semi-skilled & 5 Lower Supervisory & Low \\
\hline Bath Attendant & D Semi-skilled & 6 Semi-routine & Low \\
\hline Washerwoman/Laundress & E Casual & 7 Routine & Very low \\
\hline
\end{tabular}


While every swimming-related life-course reflected the context in which it was lived, the evidence suggests that the careers of many of these women did not always conform to the discourses surrounding the impact of the 'domesticity' ideology on gender employment patterns in this period. The way in which they transgressed traditional notions of separate spheres reinforces the argument that gender roles were not always constrained by stereotypical and artificially created boundaries, especially among those who straddled the boundaries between the working and middle classes. This highlights the need for historians to avoid writing about the middle class as one amorphous mass and making assumptions about the extent that values were shared across this class. The 'separate spheres' ideology was often stretched at the edges and women's involvement was not inevitably restricted by ideological limitations that may have been rigorously applied only within certain middle-class constituencies. Having said that, the data also suggests that, for many female swimming communities, the influence of patriarchy in determining career choices may well have been significant. Female natationists were almost always introduced to the activity through fathers and brothers, swimming mistresses entered their careers through male connections, and matrons were almost exclusively engaged as an adjunct to their husband's appointment. In these respects, even though their lives might apparently challenge rigid notions of 'separate spheres', it is possible that few of these women really exercised any significant degree of self-determinism in their life choices, although it is also quite likely, of course, that those who later became successful in their careers may well have been grateful for the opportunity.

While prosopography has been useful in uncovering some common characteristics of these different but related swimming groups and identifying their social networks, ${ }^{86}$ this analysis highlights the limitations of relying solely on quantitative methodology, and much more work needs to be done to uncover what John Bale called the 'layers of truth' surrounding these female careers. ${ }^{87}$ These prosopographical catalogues, based primarily on census data, have proved useful in helping to identify future research directions and have enabled evaluation and experimentation to occur before more detailed studies focusing on individuals and collectives are undertaken. ${ }^{88}$ However, they need to be treated with caution. Edward Higgs stressed that quantitative data is not necessarily 'raw material' for unbiased scientific analysis. It is also a human construct and if census collection and recording was itself part of the process by which gender divisions were defined, it cannot be used uncritically to study these divisions in Victorian society. Without knowledge of local economic and social conditions and a grasp of how census data collection changed, the historian could end up building 'elaborate quantitative mansions on shifting archival sands' ${ }^{89}$ It is essential, therefore, that prosopography is combined with other methods of biographical research to produce what Matthew Jockers calls, a 'blended approach'. ${ }^{90}$ Diverse interrogations and interpretations of the source material, presented through different modes of expression, will rarely, if ever, result in a consensus. However, they all add to the richness of the history landscape, which can often emerge only from a more detailed reading of individual biographies, such as that of Nellie Easton. This type of research makes connections between historian and subject in a way that is not possible with prosopography and reflects the dynamic relationship that always exists between the historian and the past. E.H. Carr, for example, emphasized the historian's need of imaginative understanding for the people being considered and argued that history cannot be written unless the historian can connect with the mind of those being studied. ${ }^{91}$ Generating an 
emotional engagement with individual biographies brings with it of course some inherent dangers and there is always a need for vigilance since historians sometimes veer too far towards the production of hagiographies that only record the positives of a life course. Given that many sources are biased or distort and filter the 'truth', all of them need interpretation and as this exploration into female swimming careers progresses, through an ongoing combination of methodologies and the careful triangulation of sources, confidence in the interpretations presented here will mature to the point at which they satisfy Martin Johnes' ambition for a history where 'assertions are qualified and the nuances of the past are clear' ${ }^{92}$

\section{Notes}

1 'Statistics as to the Employment of the Female Population of Great Britain', English Woman's Journal March 1, 1860, 1-2.

2 National Readership Survey. Approximated Social Grade, UK Office for National Statistics. http://www.nrs.co.uk/nrsprint/lifestyle-and-classification-data/social-grade/ (accessed 9 September 2017)

${ }^{3}$ Ivy Pinchbeck, Women Workers and the Industrial Revolution, 1750-1850 (London: Virago Press, 1981), 315.

4 Diana Cordea, 'Two approaches on the philosophy of separate spheres in mid-Victorian England: John Ruskin and John Stuart Mill', Procedia - Social and Behavioral Sciences 71 (2013): 115-122.

${ }^{5}$ Leonore Davidoff and Catherine Hall, Family Fortunes: Men and Women of the English Middle-Class, 1780-1850 (London: Hutchinson, 1987).

${ }^{6}$ Robert B. Shoemaker, Gender in English Society, 1650-1850: The Emergence of Separate Spheres? (Harlow: Pearson Education Limited, 1998), 6-7.

${ }^{7}$ Beverly Lemire, The Business of Everyday Life: Gender, Practice and Social Politics in England, c.1600-1900 (Manchester: Manchester University Press, 2005), 4, 13.

${ }^{8}$ Amanda Vickery, 'Golden Age to Separate Spheres? A Review of the Categories and Chronology of English Women's History', The Historical Journal 36, no. 2 (1993): 383; Shoemaker, Gender in English Society, 9-11.

${ }^{9}$ Theodore Koditschek, 'The Gendering of the British Working Class', Gender \& History 9, no. 2 (1997): 345.

${ }^{10}$ Geoffrey Best, Mid-Victorian Britain, 1851-1875 (London: Weidenfeld and Nicolson, 1971), 100.

${ }^{11}$ Gerry Holloway, Women and Work in Britain since 1840 (London: Routledge, 2005), 96-126.

12 Mary Poovey, Making a Social Body. (Chicago: University of Chicago Press, 1995).

${ }^{13}$ Hannah Barker, 'A Grocer's Tale: Gender, Family and Class in Early Nineteenth-Century Manchester', Gender \& History 21, no. 2 (2009): 340-357.

${ }^{14}$ Richard Holt, 'Sport and History: The State of the Subject in Britain', Twentieth Century British History 7 no. 2 (1996): 231.

15 Dave Day and Wray Vamplew, 'Sports History Methodologies: Old and New', The International Journal of the History of Sport 32, no. 15 (2016): 1715-1724.

16 Wray Vamplew, 'Successful Workers or Exploited Labour? Golf Professionals and Professional Golfers in Britain 18881914', Economic History Review 61, no. 1 (2008): 54-79.

17 Samantha-Jayne Oldfield, 'Narrative Methods in Sport History Research: Biography, Collective Biography, and Prosopography', The International Journal of the History of Sport 32, no. 15 (2015): 1855-1882.

18 Philip Abrams, Historical Sociology (New York: Cornell University Press, 1982).

${ }^{19}$ Lemire, The Business of Everyday Life, 2.

20 Joyce Kay, 'It Wasn't Just Emily Davison! Sport, Suffrage and Society in Edwardian Britain', The International Journal of the History of Sport, 25, no. 10 (2008): 1349-1350; Jeffrey Hill, 'British Sports History: A Post-Modern Future?', Journal of Sport History 23, no. 1 (1996)

${ }^{21}$ Vickery, 'Golden Age to Separate Spheres?', 413-414.

22 Oldfield, 'Narrative Methods in Sport History Research', 1855.

${ }^{23}$ Census Returns of England and Wales, 1841-1911. Kew, Surrey, England: The National Archives of the UK (TNA): Public Records Office (PRO).

${ }^{24}$ Susie Steinbach, Women in England, 1760-1914: A Social History (London: Weidenfeld \& Nicolson, 2004)..

25 Dave Day, 'Natational dress: functionality, fashion and the fracturing of separate spheres in Victorian Britain', Annals of Leisure Research 19, no. 2 (2016): 162-179.

${ }^{26}$ Catriona Parratt, 'Little Means or Time: Working-class Women and Leisure in late Victorian and Edwardian England', The International Journal of the History of Sport 15, no. 2 (1998): 36-37.

27 Kathleen McCrone, Feminism and Women's Sport in Late-Victorian England (Leicester: Centre for Research into Sport and Society. University of Leicester, 1991, 1998).

28 Jennifer Hargreaves, 'Recreative and competitive sports: expansion and containment' in Sporting Females: Critical Issues in the History and Sociology of Women's Sports, Jennifer Hargreaves, ed.(London: Routledge, 1994): 90; 'Changing Images of the Sporting Female. 1: Before the First World War', Sport \& Leisure (July/August 1990): 14-15. 
${ }^{29}$ Kathleen McCrone, Hockey's but a Game for Men...': The Development of Team Sports for Women, c.1880-1914 (Leicester: Centre for Research into Sport and Society. University of Leicester, 1998): 165, 182.

${ }^{30}$ Kathleen McCrone, 'Class, Gender, and English Women's Sport, c. 1890-1914', Journal of Sport History 18, no. 1 (1991): 160, 179.

${ }^{31}$ Catriona Parratt, 'Athletic Womanhood: Exploring Sources for Female Sport in Victorian and Edwardian England,' Journal of Sport History 16 (1989): 140-57.

32 McCrone, 'Class, Gender, and English Women's Sport', 160, 179.

${ }^{33}$ Claire Parker, 'Swimming: The "Ideal" Sport for Nineteenth-century British Women', The International Journal of the History of Sport 27, no. 4 (2010): 675-689.

${ }^{34}$ Frances Hoggan, Swimming and Its Relation to the Health of Women (London: Women's Printing Society, 1879).

${ }^{35}$ Claire Parker, 'The Rise of Competitive Swimming 1840 to 1878', The Sports Historian 21, no. 2, 66

${ }^{36}$ Christopher Love, 'Local Aquatic Empires: The Municipal Provision of Swimming Pools in England, 1828-1918', The International Journal of the History of Sport 24, no. 5, 622-627.

37 'Girls' swimming competition,' Woman's Herald, September 28, 1893, 502.

38 The Lady Dressmaker [pseud.], 'Frocks for To-morrow,' Girl's Own Paper, November 26, 1898, 136.

${ }^{39}$ Susan Kingsley Kent, Gender and Power in Britain 1640-1900 (London: Routledge, 1999), 180.

40 'Notes and gleanings,' Lloyd's Weekly Newspaper, July 3, 1892, 8.

${ }^{41}$ Christopher Love, 'Holborn, Lambeth and Manchester: Three Case Studies in Municipal Swimming Pool Provision', The International Journal of the History of Sport 24, no. 5, 632-633.

42 Dave Day, '"What Girl Will Now Remain Ignorant of Swimming?" Agnes Beckwith, Aquatic Entertainer and Victorian Role Model', Women's History Review 21, no. 3 (2012): 419-446.

43 'Young Ward's channel swim,' Penny Illustrated, September 22, 1883, 186; Census Returns, Alfred W. Ward, Minnie and Alfred 1881 (172/13/20); Alfred W., Alfred E., Florence, Ernest and Maud Ward 1891 (22/86/1); Minnie Ward 1891 (82/73/13).

44 Swimming Notes, March 22, 1884, 4; The Swimmer: A Journal Devoted to Natation 1, no. 6 (April 10, 1886): 58; 'Presentation to Miss Finney,' Daily News, December 20, 1889, 3;. 'Memorial notices,' Manchester Guardian, August 29, 1903, 5; 'Ladies' day at the club,' New York Times, November 11, 1894, 9; 'Notes of the stage,' December 23 1894, 8; 'Swimming,' Evening Post, November 17, 1897, 5; 'Music hall gossip,' Era, December 15, 1900, 91; 'At the variety theatres,' Hull Daily Mail, December 27, 1905, 3; 'Finney, the English swimmer, here,' New York Times, November 24, 1906, 11; 'Vaudeville,' January 13 1907, 22; 'The stage,' Morning Oregonian, August 16, 1908, 2; 'Amusements,' Duluth News Tribune, December 24, 1910, 4; 'James Finney, speed and fancy swimmer,' January 21, 1911, 9; 'New bills open at the vaudeville houses,' Morning Oregonian, March 14, 1911, 11; Census 1911, Maud Evelyn Finney (26) and Ethel Gladys Finney (21), 'Professional Swimmers' (RG14PN2229RG78 PN76RD26SD3ED9SN317).

45 'How to learn to swim,' Leeds Times, October 15, 1859, 6.

${ }^{46}$ T. Herbert Braker, 'Tracts of the Ladies' National Association for the Diffusion of Sanitary Knowledge', The MedicoChirurgical Review, and Journal of Medical Science (1859): 115.

47 'Female natation,' Bell's Life, September 27, 1879, 5.

48 Excelsior Swimming Club' Women's Penny Paper, October 5, 1889, 8.

49 Ian Keil and Don Wix, In the Swim: The Amateur Swimming Association From 1869 To 1994 (Leicester: Swimming Times Ltd., 1996), 22.

50 Swimming Notes, May 10, 1884, 8.

51 Keil and Wix, In the Swim, 21.

52 1854. April 30 Baptism - Harrow Weald, Middlesex. Parents Charles, a cordwainer, and Emma Dear.; 1861 Census RG 9/693 Schedule 138. Colebook Place, St Peter Colebrook/Saint Maurice, Winchester. Charles Dear, 30, Boot maker born in Harrow, Middlesex, Emma Dear, 28, born in Bodggley, Hampshire, Charles (8), Fanny (7) and James (3) plus William (6 months); 1873. May 12 Marriage. Paris Church, St Marks, Notting Hill, Middlesex. Fanny Elizabeth Dear, 19, Spinster, 235 Portobello Road, to James Allford, Tin Smith, 25 St Marks Road, son of Thomas Allford, brush maker.

53 1874. In Her Majesty's Court for Divorce and Matrimonial Causes. James Allford v Fanny Elizabeth Allford \& Levi Jackson. Court Minutes: Petition Filed 18 May 1874: Decree Nisi 11 November 1874: Final Decree 25 May 1875.

54 1877. February 25. Married in St Mark's Church, St Marylebone, Middlesex; 1881 Census RG 11/337 Schedule 153. 26 Gloucester Street, St George Martyr, Finsbury. David H. Easton, 22, shorthand writer born in Chelsea Middlesex, and Fanny E. Easton, 26, swimming mistress born in Harrow, Middlesex.

55 'How the world wags,' Penny Illustrated, October 5, 1889, 294.

56 'The Webb benefit entertainment,' Era, September 8, 1883, 4; 'The Marble Baths, Junction Road, Holloway,' Bell's Life, April 16, 1885, 4; 'Amusements,' Bristol Mercury and Daily Post, July 22, 1885, 4; 'Swimming,' Bell's Life, May 4, 1886, 4; 'Clipping swimmers at Islington,' Penny Illustrated, April 14, 1888, 234; 'Ipswich swimming festival,' Ipswich Journal, August 10, 1888, 7; 'Swimming,' Licensed Victuallers' Mirror, May 7, 1889, 179; 'Colchester Swimming Club,' Essex Standard, August $2,1890,5$.

57 'Topics of the day,' Western Daily Press, August 29, 1888, 5; 'Amusements,' Bristol Mercury, August 29, 1888, 4; 'Aquatic sports at Kingsdown,' August 30, 1888, 8.

58 'Aquatic entertainment,' Bath Chronicle and Weekly Gazette, November 1, 1888, 3.

59 'Life in London,' Licensed Victuallers' Mirror, September 11, 1888, 390.

60 'Leander Swimming Club,' Bristol Mercury, September 11, 1890, 3. 
61 'The Islington Public Baths', Morning Post, July 27, 1892, 3.

62 'Ilfracombe,' North Devon Journal, August 13, 1891, 2.

63 'Aquatic sports at Kingsdown Baths,' Western Daily Press, September 10, 1891, 7.

64 'Notes and gleanings,' Lloyd's Weekly Newspaper, July 3, 1892, 8.

65 'Bank holiday at Ilfracombe,' Exeter and Plymouth Gazette, August 2, 1892, 5.

66 Untitled, Standard, October 3, 1892, 6.

67 'Girls' swimming competition,' Woman's Herald, September 28, 1893, 502.

68 'How the world wags,' Penny Illustrated, September 29, 1894, 198.

691891 Census RG 12/141 Schedule 450. 8 Girdlestone Road, St Peters, North Islington. David H. Easton, 33, shorthand writer, and Fanny E. Easton, 35, swimming mistress; 1901 Census RG 13/1253 Schedule 253. 2 Elm Villas, Black Boy Lane, St Anns, West Green, Tottenham, Middlesex. David H. Easton, 42, shorthand writer (worker) and Fanny E. Easton, 44, swimming mistress (Own account); 1911 Census Schedule 146. The Elms, 43 Black Boy Lane, West Green. David H. Easton, 54, law clerk working for solicitor, and Nellie Easton, 55, swimming Instructress working on her 'Own account' at the County Council Public Baths. Also in household, Nellie's mother, Emma Dear, 78, niece Daisy Brion, 24, and niece May Brion, 18, an assistant swimming instructress at County Council Public Baths.

70 1919. Died 19 June. Probate London 25 July to Charles Dear, retired bootmaker, Williams Phillips, school keeper, and Louisa Phillips, his wife. Effects $£ 2,723$ 10s. 9 d.

71 Census Returns, William Tuohy 1841 Scottish Census 493/7/24/18. 1851 (1589/425/3); 1861 (648/65/30); 1871 (1131/45/10); 1881 (1150/52/24); 1891 (2689/62/7); 1901 (986/77/6); GRO (1902/death/Portsmouth/2b/348); Annie and Ada Tuohy 1901 (3184/46/29).

72 'Chelsea and South Kensington Swimming Baths,' Bell's Life, October 11, 1879, 5.

73 Lady Di. [pseud.], 'The world of sportswomen,' Hearth \& Home, September 7, 1893, 564; Lady Di. [pseud.], 'The world of sportswomen,' October 12, 1893, 740; Lady Di. [pseud.], 'The world of sportswomen,' June 13, 1895, 164; Lady Di. [pseud.], 'The world of sportswomen,' July 18, 1895, 354; Lady Di. [pseud.], 'The world of sportswomen,' August 1, 1895, 423; Lady Di. [pseud.], 'The world of sportswomen,' December 12, 1895, 200; Lady Di. [pseud.], 'The world of sportswomen,' December 19, 1895, 230.

74 'Southsea Baths and Rooms Company,' Hampshire \& Portsmouth Telegraph, December 24, 1873, 4.

${ }^{75}$ Where are the teachers of swimming? The Scotsman, September 7, 1887, 9.

76 'Persons wanted,' Liverpool Mercury, April 20, 1899, 1.

77 Annals of the Liverpool Corporate Baths Dept., 1952, 29, cited in Parker, 'The Rise of Competitive Swimming', 62.

78 Swimming Notes, May 10, 1884, 8.

79 Polly Bird, (1995). 'The Origins of Victorian Public Baths, with Special Reference to Dulwich Baths', Local Historian 25, 149 150.

${ }^{80}$ Steinbach, Women in England.

81 Keith Myerscough - personal communication.

82 Simon Graham Allen, The Provision of Public Baths and Wash Houses in Cardiff and their Effect on Victorian Public Health and Hygiene, 1846-1901. MA thesis, University of Wales Institute, Cardiff, September 1998, 66.

83 Bird, 'The Origins of Victorian Public Baths', 149-150.

84 Lady Di. [pseud.], 'The world of sportswomen,' Hearth \& Home, September 7, 1893, 564; Lady Di. [pseud.], 'The world of sportswomen,' October 12, 1893, 740.

${ }^{85}$ Census Returns 1861-1891. John Howarth 1861 (4440/252/18), 1871 (3874/119/37). John, Agnes, Frances and Edith A. Howarth 1881 (3750/55/40), 1891 (3036/133/37).

86 Stone, 'Prosopography'; Keats-Rohan, ed., Prosopography Approaches and Applications: A Handbook. (Oxford: Oxford University Press, 2007).

87 John Bale, 'Ernst Jokl and Layers of Truth', in Sporting Lives, ed. Dave Day (Manchester: MMU IPR Publication, 2011), 1-15.

${ }^{88}$ Robin Fleming, 'Writing Biography at the Edge of History', American Historical Association Review 114, no. 3 (2009): 606614.

89 Edward Higgs, A Clearer Sense of the Census (London: Public Record Office, 1996).

90 Matthew L. Jockers, Macroanalysis: Digitial Methods and Literary Theory (Urbana: University of Illinois Press, 2013 ), 26.

${ }^{91}$ E.H. Carr, What is History? (Cambridge: Cambridge University Press, 1961).

92 Martin Johnes, 'Archives, Truths and the Historian at Work: A Reply to Douglas Booth's "Refiguring the Archive"', Sport in History 27, no. 1 (2007): 127-135. 